\title{
"ISRAEL CAN HARDLY BE A JEWISH STATE AND A DEMOCRACY AT THE SAME TIME
}

Israel should divide religion and politics. Today's system encourages ethnic discrimination towards the Arab Israelis, and having a minority who lives on crumbs is a recipe for political instability and a flawed democracy. 
TEXT: Tilde Rosmer

ACCORding to professor Ilan Peleg, the tension between the particularistic definiton of the state of Israel as "Jewish" and the universalistic values of democracy are extremely difficult to reconcile. The Jewish carachteristic of the state has produced inequality between Arab and Jewish citizens. Any state with a pluralistic population on the one hand, and a particularistic definition on the other, is likely to find itself discriminating segments of the population that does not belong to the particularistic identity which the state promotes, according to Peleg.

Peleg is the Charles A. Dana Professor of Government and Law at Lafayette College and has written several books and numerous articles on issues relating to the Middle East and Israel in particular. He is the editor of Israel Studies Forum ${ }^{\mathrm{I}}$ and a frequent commentator on Middle East affairs in the us media. In his research, Peleg focuses on Middle East and international relations and in particular Israel as an ethnic state, human rights and Israeli foreign policy, Israel's judiciary and political culture. Born and raised in Israel, Peleg has served in the Israel Defence Forces, but has been living in the United States since I97I. His research is comparative in nature and covers especially the Middle East, Europe and North America. He recently was a Senior Academic Associate at St. Anthony's College in Oxford, where he worked on a book entitled «Democratising the Hegemonic State».

Peleg maintains that the Israeli state fullfills many of the central charachteristics of a democracy such as open elections, free press, strong public debates and free judiciary. This is the background for the general belief and pride among Israelis and others that "Israel is the only democracy in the Middle East”. Indeed, Peleg observes that within the Jewish population of Israel, democratic traditions with electoral systems built on the notion of proportional representation, has deep roots going back to the traditional Jewish communal organisation through to modern Zionist (preState) institutions. However, I interpret Peleg as saying that Zionism has difficulties in being entirely democratic outside of the Jewish population because it is by defintion an ethnically-based ideology.

Moreover, the tendency of some Zionists to link this modern nationalist movement with religion (Judaism) leads not only to discrimination between Jews and nonJews, but also to irreconcilable differences between secular and religious Jews. In several articles, Peleg has characterised the 
Israeli model as an "ethnic constitutional order". He focuses on the material implications of this state-control model which, according to him, leads to systematic ethnic discrimination, examplified by the difficulties Arab Israelis (the term Arab Israeli is used in order to differenciate between Arab citizens of Israel and Palestinians) face when purchasing land and their exemption from military service. According to Peleg, the foundation of this ethnic order was laid by David Ben-Gurion, Israel's Founding Father, in I948. Of the five possible choices (Halachic Zionism based on Jewish religious law, binationalism, socialist democracy, liberal democracy and ethnic order) Ben-Gurion chose the one guaranteeing Jewish dominance over all aspects of Israeli life: territory, immigrant policy, the military, the educational system, and national symbols and national identity as a whole. This type of regime, says Peleg, amounts to "an inherently flawed democracy" with a state that is not neutral in its treatment of its citizens.

In the case of land purchase, most of the land for sale in the state of Israel is owned by a Jewish organisation (The Jewish Agency) who will only let Jewish Israelis purchase land. In this way, the state is indirectly allowing discrimination against its non-Jewish citizens (mostly Arab). Peleg says: "Even the Israeli Supreme court, not exactly a friend to the Arabs, ruled in March of 2000 that these practices amount to discrimination and ruled that they must stop".

When it comes to military service, Arab citizens of Israel are "exempted" from this duty by an administrative decision of the Defense Minister. This has two important consequences according to Peleg: first, it de-legitimises Arabs as members of Israeli society. Military service in Israel is compulsory for men for three years and two years for women, and is one of the most important "identity-markers" of national belonging for young Israelis. Arab citizens are not given the opportunity to take part in these important developments and institutions of identity-making, and are thereby segregated from the majority of the Jewish Israeli population. Secondly, exemption from military service takes away opportunity to receive benefits and rights given to Israelis after the completion of this service.

Some would argue that Arabs in Israel do not wish to serve in the Israeli army. Does not assuming that they do imply a "colonialist" attitude? To this Peleg replies that it is the responsibility of the state to convince its Arab citizens to undertake the civil obligation of participation in the military. He suggests alternative or civil service for citizens who do not want to serve in the fighting units of the military, regardless of religious or ethnic origin.

"The religious legislation in Israel is undemocratic", according to Peleg. He argues that the transfer of power over private law to religious authority in Israel has several undemocratic consequences. He explains how the religious issue cuts across almost all issues in the state of Israel from economy to the military, education and foreign policy. In economic allocations from the Ministry of Religion, Peleg sees discrimination first in favor of the Jewish population, and then within this population in favor of Orthodox Judaism. This way the religious institutions and legacy not only discriminates towards the Arab citizens of Israel, but it increases the divide between religious and non-religious Jewish citizens. 
First of all, civil marriage is not an option and thus makes intermarriage between individuals of different religious affiliations impossible. This results in the phenomenon of "Cyprus marriages", wherein Israeli citizens are "forced to" go to Cyprus to be wed by a civil court. Peleg notes that Israel is "probably the only democracy or semi-democracy that does not allow civil marriage". "Even nondemocracies allow that kind of freedom", he says.

Secondly, Orthodox Judaism represents the state version of Judaism in state-sponsored institutions such as the Chief Rabbinate, the local religious councils, the reli-

\section{Education is another important issue where religious authorities plays an important, but negative, role.}

gious judges, funeral agencies and kosher supervising. According to Peleg, tens of thousands are employed by these institutions that are economically sustained by a majority of Jewish Israelis that do not define themselves as Orthodox Jews.

"The emergence of religious political parties is another consequence of the transfer of legal authority over personal matters to religious authorities", according to Peleg. He uses the Sephardi party Shas as example. The Shas party advocates a return to traditional Judaism as expressed in its slogan Lehazair Atara le' Yoshna ("To Restore the Crown to Its Ancient Glory”). Though Shas uses the democratic institutions of the state to represent and enforce its policies, Peleg sees this party as an example of the furtherance of religious authoritative and un-democratic power. As examples he refers to the hierarcichal internal stucture in Shas with the 82 year old rabbi Ovadia Yosef as its absolute authority, and the Shas policy of having no female representatives. An illustrative example is the views of democracy and the state of Israel as expressed by Itzhik Sudri, spokesman of Shas, saying that the state has to be Jewish and democratic, but first of all Jewish. By this he means that in the case of conflicting issues, democracy has to give way for the Jewish point of view or to Judaism. ${ }^{2}$ Peleg believes in separation between religion and state as an important part of democratic development and points to the Western world and especially the US as examples. Even in places where separation has not been achieved, as in the UK, Peleg observes the "political marginalisation of religious authority" which, he hasten to add, is "one of the greatest blessings of modern democracy".

Education is another important issue where religious authorities plays an important, but negative role, in Peleg' s view. In Israel the school system is divided among secular state schools, religious state schools, orthodox schools and Arab schools. "This system creates several different, and hostile, groups of citizens", says Peleg. The educational opportunities are grossly uneven and there is almost exclusive emphasis on Jewish history and values, to the exclusion of Arab/Palestinian history and values. To illustrate this Peleg points to the fact that all schools have to teach about the Holocaust, but only Arab schools study Al-Nakba ("The Disaster", the 1948 War in Palestinian perspective and historiography). 
Can the state of Israel solve these problems? Peleg admonishes Israel to move from the ethnic order which in I948 created what he calls "a Jewish Republic", to a liberal democracy. In a liberal democracy all individuals are politically and legally equal, with protected constitutional rights. He describes this as the Western legacy that could ensure social and political stability.

Peleg, who emphasises that he is not anti-religious, calls for the privatisation of religion. This way the division among the secular and religious Jewish citizens would

\section{Peleg admonishes Israel to move} from the ethnic order which in 1948 created a "Jewish republic".

decrease, as would also the Arab-Jewish divide. Privatisation of religion would eliminate religious interference in people' s life. Moreover it would help decrease the gap between Israel's ethnic groups and define citizens as individuals, not as part of one particular religious group or another. Religious affiliation should be the personal choice of the individual Israeli, he emphasizes.

In a lecture given at the Oxford Centre for Hebrew and Jewish Studies, Peleg argued that is is possible for Israel to be "Jewish" and "democratic", but those concepts have to be carefully re-defined, so that democracy is maximized and the state's Jewishness constrained. As long as its majority is Jewish, Israel will naturally have a Jewish identity, he said. However the state needs to be neutral and avoid the allocation of rights in accordance with ethnicity. The state of Israel is described as an "ethnic democracy" by other scholars such as Sammy Smooha, Professor of Sociology at University of Haifa. Smooha defines Israel as an ethnic democracy giving civil and political rights to all citizens but institutionalising control over the state by the ethnic majority. An alternative term to describe the Israeli state system is "ethnocracy" as suggested by Oren Yiftachel of Ben-Gurion University, meaning that the state is controlled by one ehtnic group whose services and interests are put forward at the expenses of other ethnic groups. ${ }^{3}$ It is interesting to note that Smooha speaks of the differences between the Ashkenazi (European) and the Mizrahi (Middle Eastern) Jews as in the same context as when he talks about differences among citizens and state domination, alluding to the differences between Ashkenazi and Mizrahi Jewish Israelis.

Although Peleg is a personal friend of both Smooha and Yiftachel, he disagrees with both. According to Peleg, ethnic democracy, as defined by Smooha, is a contradictory term. Although he argues that an "ethnic" Israel can be democratic, the parameters of its ethnicity and their contents must be redefined and substantially narrowed. Thus, Peleg calls for a new policy on national symbols. He argues that Israel's Arab population would identify more with the state if the symbols of that state cease to be exclusively Jewish. As of today the Israeli flag, the national anthem (that speaks of the yearning Jewish soul), and all official holidays are based exclusively on Jewish tradition, history, and culture. As an alternative model to liberal democracy, that could also fit Israel's 
needs, Peleg suggests the "consociatonal democracy" model of Arend Lijphart. The term "consociationalism" describes the sharing of power between segments of society joined together by a common citizenship, but divided by ethnicity, language, religion or other factors. This model is suitable for deeply divided societies and is based on a division of power between the different population groups in a coalition governments. According to Peleg, the consociatonal democracy can be an alternative model for Israel precisely because in liberal democracies the majority will always rule. He continues to explain that there is a certain consociatonal division between the different Jewish groups in Israel today. However, the Israeli Arabs are not part of this framework and even though they do participate in the democratic institutions of the state they have little, if any, real political power. Rather, they have to accept or decline what the majority offers them. "A minority who lives on crumbs," says Ilan Peleg," is a recipe for political instability and a flawed democracy."

$$
\text { - } f \cdot
$$

Tilde Rosmer, cand. philol/Historian of Religion, had the pleasure of meeting and talking with Professor Ilan Peleg at the Oxford Centre for Hebrew and Jewish Studies. This article is based on an interview with Prof. Peleg and notes from lectures he gave on different occasions in Oxford autumn 2002 and winter 2003. Professor Peleg could be reached at pelegi@lafayette.edu or at 001-610-330-5396.

For further reading on Ilan Peleg and the origins of the condition of the Israeli democracy see Ilan Peleg, “Israel' s Consti- tutional Order and Kulturkampf: The Role of Ben Gurion", Israel Studies 3, no.I, I998; «Human Rights in the West Bank and Gaza» (Syracuse University Press, I995); Ilan Peleg' s «The Peace Process in The Middle East», (SUNY Press, I998), where Prof. Peleg wrote the concluding chapter.

'Published by Association for Israel, an international, interdisciplinary scholarly society devoted to the academic and professional study of Israel.

${ }^{2}$ Rosmer, Tilde, 2002, "SHAS, The Sephardi Torah Guardians and their Construction of the New Jewish Israeli Identity", Hovedfagsoppgave i Religionshistorie, Universitetet i Oslo, p 65

${ }^{3}$ See Jeff Spinner-Halev "Unoriginal Sin: Zionism and Democratic Exclusion in Comparative Perspective", Israel Studies Forum, Fall 2002, vol. I8, \#I for a presentation of these terms and perspectives. 